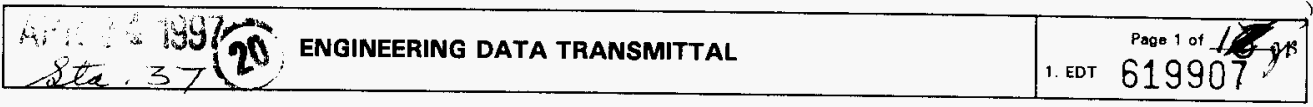

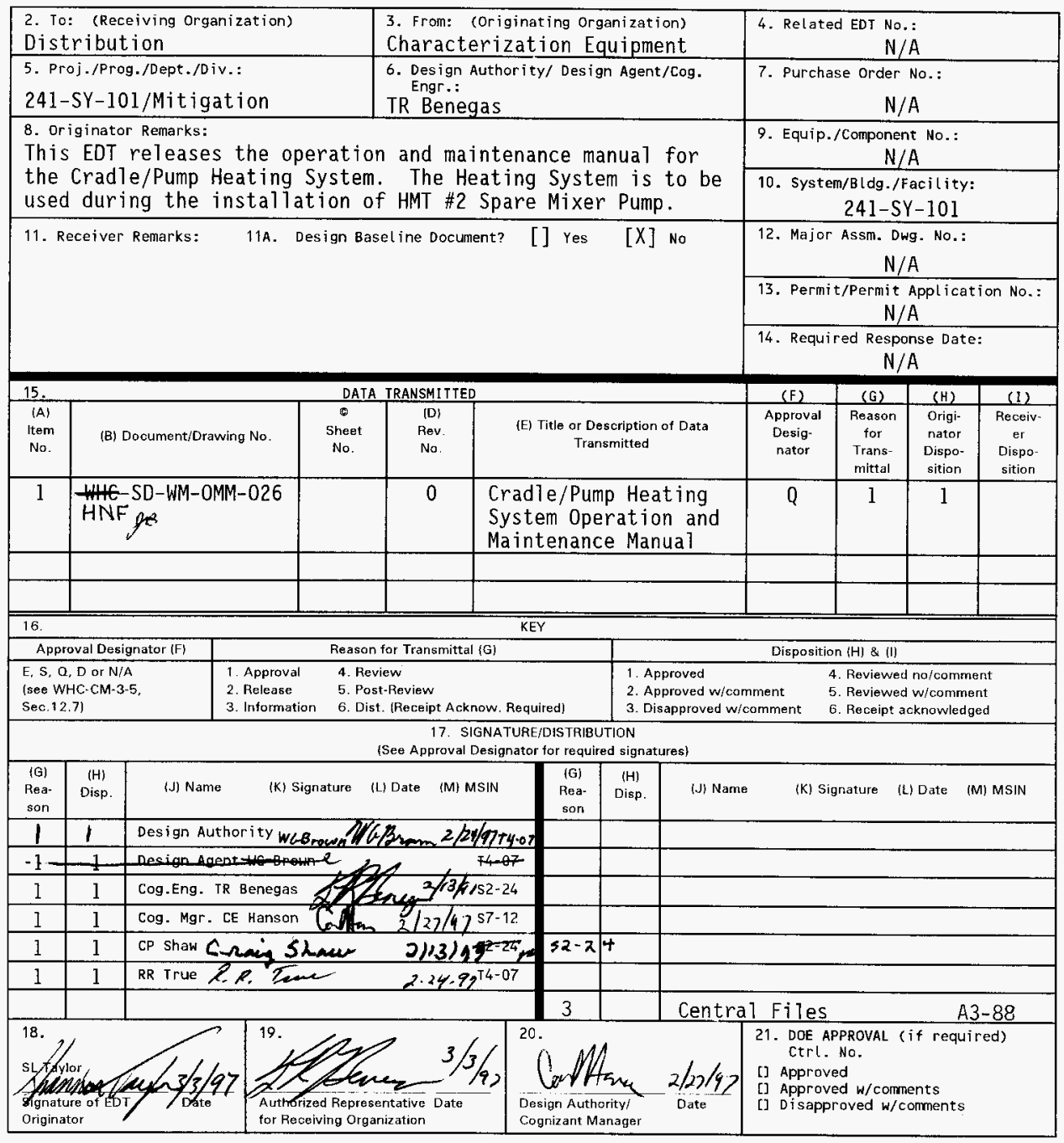

BD $-7400-172-2(05 / 96)$ GEF097 


\section{Cradle/Pump Heating System Operation and Maintenance Manual}

Shannon L. Taylor

Merrick \& Company, Richland, WA 99352

U.S. Department of Energy Contract DE-AC06-96RL13200

$\begin{array}{lll}\text { EDT/ECN: } & 619907 & \text { UC: } 2030 \\ \text { Org Code: } & \text { H525 } & \text { Charge Code: N2138 N2169 po pes s<r } \\ \text { B\&R Code: } & \text { EW3120072 } & \text { Total Pages: }-78 ; 10\end{array}$

Key Words: Pump Heating Skid, HMT \#2, 241-SY-101 Pump

Abstract: This is the operation and maintenance manual for the 241-SY-101 Cradle/Pump Heating System. The Heating System provides the means to heat the pump (HMT \#2) during cold weather to assure safe and smooth pump installation.

TRADEMARK DISCLAIMER. Reference herein to any specific comercial product, process, or service by trade name, trademark, manufacturer, or otherwise, does not necessarily constitute or imply its endorsement, recommendation, or favoring by the United States Government or any agency thereof or its contractors or subcontractors.

Printed in the United States of America. To obtain copies of this document, contact: Document Control Services, P.O. Box 950, Mailstop H6-08, Richland WA 99352, Phone (509) 372-2420; Fax $(509) 376-4989$
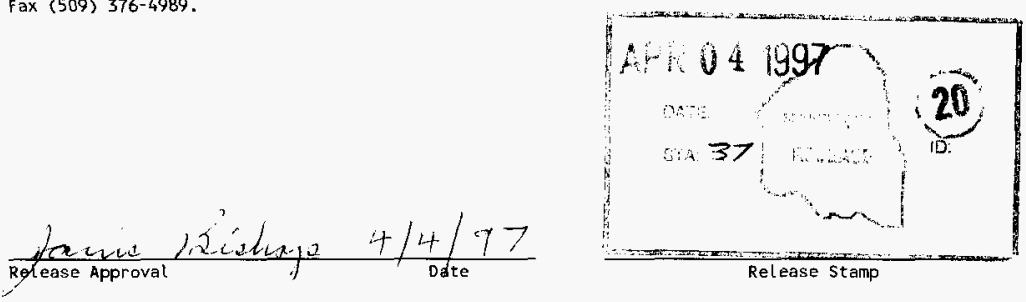

\section{Approved for Public Release}


HNF-SD-WM-OMM-026

Rev 0

\section{CRADLE/PUMP HEATING SYSTEM OPERATIONS AND MAINTENANCE MANUAL}

February 1997

Fluor Daniel Hanford 
HNF-SD-WM-OMM-026

REV 0

\section{TABLE OF CONTENTS}

1.0 GENERAL EQUIPMENT INFORMATION $\ldots \ldots \ldots \ldots \ldots \ldots \ldots \ldots \ldots \ldots \ldots \ldots$

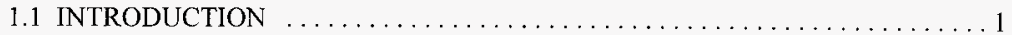

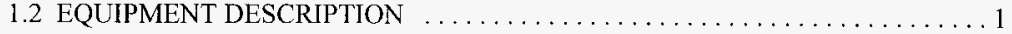



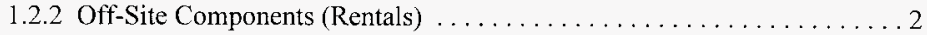

1.2 .3 Purchased Components (Disposable) $\ldots \ldots \ldots \ldots \ldots \ldots \ldots \ldots \ldots \ldots$

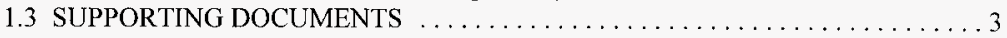

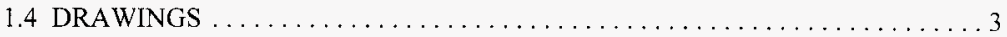

2.0 OPERATION OVERVIEW $\ldots \ldots \ldots \ldots \ldots \ldots \ldots \ldots \ldots \ldots \ldots \ldots \ldots \ldots \ldots \ldots$

2.1 EQUIPMENT AND TOOLS REQUIRED $\ldots \ldots \ldots \ldots \ldots \ldots \ldots \ldots \ldots \ldots \ldots$

2.2 SYSTEM SETUP/STAGING ON SY TANK FARM $\ldots \ldots \ldots \ldots \ldots \ldots \ldots \ldots$

2.3 SYSTEM OPERATING INFORMATION $\ldots \ldots \ldots \ldots \ldots \ldots \ldots \ldots \ldots \ldots$

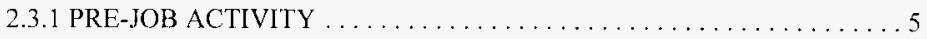

2.3.2 JOB SEQUENCE OF OPERATIONS ............... 5

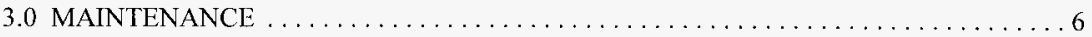

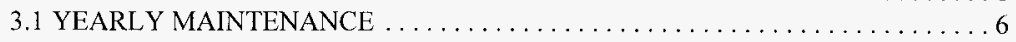

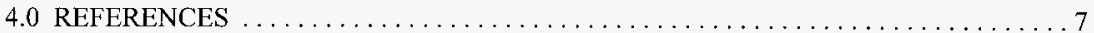


HNF-SD-WM-OMM-026

REV 0

\section{CRADLE/PUMP HEATING SYSTEM \\ OPERATIONS AND MAINTENANCE MANUAL}

\subsection{GENERAL EQUIPMENT INFORMATION}

\subsection{INTRODUCTION}

A test mixer pump was installed in tank 241-SY-101 on July 3, 1993, to support hydrogen mitigation testing. This test mixer pump has proven to be very successful in mitigating the large gas releases, or "burps," from the tank waste. Therefore, a decision has been made that upon failure of the existing test pump a spare mixer pump (HMT \#2) will be installed. A pump removal system was designed and fabricated to support the retrieval, transportation, and disposal of the existing pump. Likewise, a spare mixer pump and installation equipment have been designed, fabricated and tested to support this activity. The installation equipment to install HMT \#2 consist of the following major components:

- Cradle
- Hydraulic System
- Misc. Hardware
Lifting Beam
Heater Skid
- Propane Tank (1000 gal.)
- Adaptors / Ductwork Penetrations
- Support cranes.

This manual focuses on the operation and maintenance of the Cradle/Pump Heating System, which is used in conjunction with other equipment to install HMT \#2. The Heating System provides a means to heat the pump to assure safe smooth equipment operation during HMT\#2 installation.

\subsection{EQUIPMENT DESCRIPTION}

The a general layout of the Cradle/Pump Heating System and its ancillary equipment is shown on HMT Strongback Heater Site Layout (H-2-815390). This drawing can be used as a general reference for the inventory, testing and eventual assembly of the Cradle/Pump Heating System. 


\subsubsection{Site Maintained Equipment}

The following is a detailed description of each piece of site maintained installation equipment for the Cradle/Pump Heating System's operation (copies of the catalog page of the major components are contained in the HMT 2 CVI file, \#22522)

Stongback Heater: This heater skid includes all major components required to supply heated air to the Pump/Cradle. This includes: blowers, generator, heater and plenum assembly.

Blower: The $3 / 4$ horsepower blower draws the heated air from the plenum and through the cradle via the flex hose. The blower will provide approximately $2000 \mathrm{cfm}$ air flow.

Heater: The portable heater provides $175,000-350,00 \mathrm{BTU} / \mathrm{hr}$ for heating the air to $190^{\circ} \mathrm{F}$.

Generator: The 11 horsepower Briggs and Stratton gas powered generator provides 120/240 volts for the blower motor, heater, receptacles and duplex outlet.

Blower Hose Connection: This provides a 4" lip that allows the 20 " diameter flexible duct to be securely fastened to the hose adapter.

Hose Adaptors: This adapts the 20" diameter blower hose connection to fit on the square transition duct that distributes the air flow into the cradle ducts.

Temperature Meter: The MT4 temperature meter, manufactured by Universal Enterprises, is placed in the hose adapter to provide a temperature reading of the warm air flow into the cradle.

Misc. Fasteners: Bolts, nuts and washers are used to fasten the various ducts together and Band-It Scru-Seal clamps are used to secure the flex duct to the matting parts.

\subsubsection{Off-Site Components (Rentals)}

The following is a detailed description of each piece of off-site rental installation equipment for the strongback heater skid's operation:

Propane Tank: A 1000 gallon minimum propane tank or truck will be required for the heating of the Cradle/Pump. The rental equipment should contain the needed hoses and fittings to transfer the propane to the heater. The tank/truck will be located at least 50 feet away from the heating skid to prevent a possible fire hazard. 
Note: The above equipment would typically be available at Star Rentals or equivalent.

\subsubsection{Purchased Components (Disposable)}

The following is a detailed description of each piece of "disposable" installation equipment for the strongback heater skid's operation:

Hose: To transfer the warm air from the heating skid to the cradle and back, a $20^{\prime \prime}$ diameter heavy duty blowing/exhaust hose is required, 100' length minimum. Use McMaster-Carr item 5266K43, Bio-R-Vac Hose.

Clamps: Four, 20" diameter, Clamps are required to fastened the flexible duct to the blower, heater and hose connection. Use McMaster-Carr item 5540K11, Scru-Seal clamps.

Misc. Fasteners: Bolts, nuts and washer will be used as required to fasten the various ducts together, see drawings.

These are the fasteners called out on drawing H-2-815390. It is up to operations if they want to store these items until needed or purchase them in advance.

Note: The term, "disposable equipment" identifies equipment which is readily commercially available and might be more cost effective to purchase when needed rather then to maintain in a state of ready. Equally important, some equipment listed degrades overtime in storage.

\subsection{SUPPORTING DOCUMENTS}

The main document supporting the design and operation of the Cradle/Pump Heater System is the Thermal Analysis of Pump Assembly Prior to Insertion, WHC-SD-WM-RPT-063. The document identifies various insertion schedules based on environmental conditions (temperature, wind, etc.) relative to the pumps temperature in order for the person in charge (PIC) to make educated decisions for pump heat up prior to inserting HMT\#2.

\subsection{DRAWINGS}

The following drawings identify all major components required to layout and assemble the Cradle/Pump Heating System:

H-2-815390 HMT Strongback Heater Site Layout 
HNF-SD-WM-OMM-026

REV 0

H-2-89496

H-2-89498

$\mathrm{H}-2-89491$
HMT Equipment Installation Strongback Heater

HMT Hose Adaptor, Strongback Heater

HMT Hose Reducer

\subsection{OPERATION OVERVIEW}

The Cradle/Pump Heating System is intended to heat the pump prior to removal from the cradle. The system is designed to heat the pump to some temperature above $70^{\circ} \mathrm{F}$, in order to provide enough time for rigging the pump and inserting it into Tank 101-SY before it cools to $70^{\circ} \mathrm{F}$. This is to make certain the carbon steel in the pump is above the nil ductility temperature and not subject to brittle failure.

\subsection{EQUIPMENT AND TOOLS REQUIRED}

There are no special tools required for the installation of the Cradle/Pump Heater System. All tools and materials for the installation of the Cradle/Pump Heater System will be specified in the JCS Work Package.

\subsection{SYSTEM SETUP/STAGING ON SY TANK FARM}

Locate and assemble the strongback heater equipment per HMT Strongback Heater Site Layout (H-2-815390) and HMT Equipment Installation Strongback Heater (H-2-89496).

\subsection{SYSTEM OPERATING INFORMATION}

A blower (H-2-89496, PN 11) is designed to "pull" air through the cradle from the plenum (H-2815390, PN 6) at a approximately $2000 \mathrm{cfm}$. The plenum is fitted with 3 dampers to allow the blower to "pull" either heated air from the propane heater (H-2-815390, PN 9) or outside ambient air or both. The propane heater flows $1400 \mathrm{cfm}$. The dampers can adjust from $100 \%$ heated air to $100 \%$ outside air and any percent in between. The heater is adjustable from 175,000 to 350,000 $\mathrm{Btw} / \mathrm{hr}$.

The exact setting of the dampers is dependent of the current environmental conditions (i.e. temperature and wind). The objective is to deliver $190^{\circ} \mathrm{F}$ max air at the cradle inlet. The air will cool as it travels through the $20^{\prime \prime}$ hose from the plenum to the cradle. The temperature of the air in the plenum is measured by a thermometer (H-2-815390, PN 12). The operator is required to monitor the system's operation to assure that the temperature doesn't exceed $250^{\circ} \mathrm{F}$, which is the upper limit of the hose. The temperature drop through the hose will vary with current environmental conditions. 
If it is very cold $\left(-10^{\circ} \mathrm{F}\right)$ the hose may need to be wrapped in insulating blankets to deliver $190^{\circ} \mathrm{F}$ at the cradle and not exceed $250^{\circ} \mathrm{F}$ at the plenum.

NOTE: During the course of heating the PIC may authorize a supply temperature less than $190^{\circ} \mathrm{F}$.

\subsubsection{PRE-JOB ACTIVITY}

PIC should read and review the Thermal Analysis of Pump Assembly Prior to Insertion, WHC-SDWM-RPT-063 which provides data for the Person-in-charge (PIC) to decide whether the preheat temperature is adequate to proceed with installation based on the current weather conditions.

NOTE: Depending on the environmental conditions, it will require from 24 to 48 hours of heating to bring the pump to temperature. During this time it is likely the propane tank will need filling (it burns $17 \mathrm{lb} / \mathrm{hr}$ ) and the electric generator will need to be refueled. For safety the equipment must be turned off for refueling, the interruption to heating will be minimal if the "off" time is less than 1 hour. An operator must be in continuous attendance during the heating operation.

\subsubsection{JOB SEQUENCE OF OPERATIONS}

The following is a general overview of the typical steps for operating and controlling the Cradle/Pump Heating System:

Step 1 Start the electric generator.

Step 2 Open dampers 2 and 3, close damper 1 (H-2-89496).

Step 3 Turn on the exhaust blower.

Step 4 Turn on the propane heater, set to minimum power.

NOTE: The system is now drawing $100 \%$ outside air and by-passing all of the heat.

Step 5 Open damper 1 until the desired temperature is reached or it is open $100 \%$. If more heat is needed go to step 6.

Step 6 Close damper 3 until the desired temperature is reached or it is closed $100 \%$. If more heat is needed go to step 7 . 
Step 7 Close damper 2 until the desired temperature is reached or it is closed $100 \%$ If more heat is needed go to step 8 .

NOTE: The system is now drawing $100 \%$ heated air.

Step 8 Turn up the power on the heater until the desired temperature is reached or full power is achieved. This is the maximum output of the heater assembly.

\subsection{MAINTENANCE}

The Heating Skid with its associated parts shall be stored indoors to prevent possible damage from the outdoor environments (rain, dust, etc.). All equipment is stored at one convenient site to provide quick and easy access. The following is a brief explanation of the maintenance required for the major components:

Generator: The generator must be maintained per manufactures specification. The operator must run the generator until it runs out of gas so that no stagnate fuel is left in the tank during storage.

Blower: The blower must be maintained per manufacturers specification. Before using the blower the operator must lube the bearing and ensure that they are rotating freely.

Heater: The heater must be stored indoors to avoid rusting of the parts. All connection should be checked and tighten if needed to prevent a possible gas leak.

Temperature Meter: The MT4 meter should be stored in the case provided to eliminate environmental damage (rain, dust, wind, etc.).

\subsection{YEARLY MAINTENANCE}

Verify the above 4 (four) components are stored indoors and have not been removed from the heating skid. Currently the system is stored in the $2101 \mathrm{M}$ warehouse, 200 West area.

Verify that no parts from each of the four major components have been damaged or removed.

Perform yearly maintenance on the blower per manufacturer instructions on idle equipment. 
HNF-SD-WM-OMM-026

REV O

\subsection{REFERENCES}

WHC-SD-WM-RPT-063, 1993, Thermal Analysis of Pump Assembly Prior to Insertion, Rev 0, Westinghouse Hanford Company, Richland, Washington.

WHC, 1995, Equipment Removal System Layout (Site layout), drawing H-2-824445, Rev 0, Westinghouse Hanford Company, Richland, Washington.

LA-UR-92-3196 Rev. 14, "A Safety Assessment for Proposed Pump Mixing Operations to Mitigate Episodic Gas Releases in Tank 241-SY-101"

TFPE-YP-0214, "Instructions for Removal of the Mixing Pump From Tank 241-SY-101"

WHC-CM-6-1, "Standard Engineering Practices"

WHC-SD-WM-OTP-168, "Operability Test Procedure, Equipment Removal System"

HNF-SD-WM-SAD-033 Rev. 3, "SY-101 Mixer Pump Safety Analysis" 